\title{
PEMANFAATAN LIMBAH MARMER DAN BATUKAPUR UNTUK PEMBUATAN BATA EKSPOSE BERBASIS BODI WOLASTONIT SINTETIS
}

\author{
Utilization of Marble and Limestone Wastes for Making the Eksposed \\ Bricks Based Synthetic Wollastonite
}

\section{FRANK EDWIN dan SUBARI}

Balai Besar Keramik

Jalan Jend. Achmad Yani 392 Bandung 40272

Telp. (022) 7206221

e-mail : frankedwin@ymail.com

\begin{abstract}
ABSTRAK
Percobaan pembuatan bata ekspose berbasis bodi wolastonit sintetis menggunakan bahan baku utama limbah marmer atau batukapur lolos ayakan standar Tyler 200 mesh telah dilakukan dengan komposisi optimum campuran bahan terdiri dari 55\% serbuk marmer atau batukapur dan 45\% silika dengan kadar air $8 \%$. Pembakaran dilakukan pada suhu $1100{ }^{\circ} \mathrm{C}$, waktu penahanan selama 3 jam. Dengan menggunakan bahan utama limbah marmer diperoleh hasil uji fisis/mekanis sebagai berikut : warna bakar putih, densitas 1,47 g/cc, penyerapan air 35,72\%, porositas 52,55\%, kekerasan 4 (skala Moh's) dan kuat tekan 12,71 MPa. Sedangkan dengan menggunakan bahan utama batukapur diperoleh hasil uji fisis/mekanis sebagai berikut : warna bakar putih, densitas 1,50 g/cc, penyerapan air 31,79\%, porositas 47,80 \%, kekerasan 4 - 5 (skala Mohs) dan kuat tekan 13,09 MPa. Hasil analisis XRD menunjukkan pertumbuhan fasa kristalin wolastonit untuk bodi MP I (bahan utama limbah marmer) mencapai 41,84 $\%$. Sedangkan untuk bodi KP I (bahan utama batukapur) pertumbuhannya meningkat hampir 2 kali lipat yaitu sebesar $80,02 \%$. Hasil percobaan pembuatan bata ekspose berwarna spesifik putih ini dapat dikembangkan untuk pedestrian atau jalan taman yang mudah menyerap air, bata dinding bangunan atau bata tahan api isolasi.
\end{abstract}

Kata kunci : bata ekspose, wolastonit sintetis, limbah marmer, batukapur.

\begin{abstract}
Experiments on eksposed brick making based on synthetic wollastonite body using the main raw materials of marble waste or limestone passing 200 mesh of standard sieve had been done with optimum material composition of $55 \%$ marble powder or limestone and $45 \%$ silica with $8 \%$ water content. The firing temperature was performed at $1100{ }^{\circ} \mathrm{C}$ with soaking time of 3 hours. By using the main material of marble waste, the physical/mechanical properties of the brick are found as follows: the color of fired brick is white with $1.47 \mathrm{~g} / \mathrm{Cc}$ of density; $35.72 \%$ of water adsorption; $52.55 \%$ of porosity; 4 of Moh's hardness scale and $12.71 \mathrm{MPa}$ of compressive strength. While by using the main material of limestone the physical/mechanical properties of the brick are found as follows: the color of fired brick is also white with $1.50 \mathrm{~g} / \mathrm{cc}$ of density; $31.79 \%$ of water adsorption; $47.80 \%$ of porosity; 4-5 of hardness and $13.09 \mathrm{MPa}$ of compressive strength. The results of XRD analysis shows the growth of wollastonite phases for MP I body (main material of marble waste) reaches $41.84 \%$. As for KPI body (main material of limestone), the growth increases almost two-folds in the amount of $80.02 \%$. The experimental result of the eksposed brick making with specific white color can be developed i.e. for pedestrian or courtyard garden which is easy in adsorbing water as well as for building wall or insulation brick.
\end{abstract}

Keywords : eksposed brick, synthetic wollastonite, marble waste, limestone. 


\section{PENDAHULUAN}

Potensi cadangan batu marmer yang ditemukan di beberapa propinsi di Indonesia cukup besar, diantaranya di Kabupaten.Tulung Agung Jawa Timur dengan cadangan sebesar 4.328.500 $\mathrm{m}^{3}$, di Kabupaten Lombok Tengah sebesar $10.200 .000 \mathrm{~m}^{3}$, Kabupaten Kolaka Sulawesi Tenggara sebesar 45.865 juta $\mathrm{m}^{3}$ dan Kabupaten Pangkep Sulawesi Selatan dengan jumlah cadangan ratusan juta ton (Tushadi, 1990). Industri pemotongan dan pengolahan marmer secara keseluruhan di Indonesia menghasilkan limbah debu marmer \pm 200.000 ton pertahun dari 2 juta $\mathrm{m}^{2}$ marmer yang diproduksinya. (Suripto dkk., 2009). Marmer terbentuk dari hasil rekristalisasi batukapur (batu gamping) karena itu keberadaannya selalu berasosiasi dengan batukapur walaupun tidak setiap ada batukapur akan ada marmer. Mineral utama marmer adalah kalsit atau dolomit dan/atau kapur yang tersilifikasi, sehingga kadar silikanya tinggi. Potensi cadangan batukapur di Indonesia sangat besar diperkirakan 28,678 milyar ton, sebagian besar berada di Sumatera Barat dengan jumlah cadangan sebesar 23,23 milyar ton atau hampir $81 \%$ dari seluruh cadangan batukapur di Indonesia (Anonim, 2000).

Penelitian ini dimaksudkan untuk merealisasikan kebijakan pemerintah dalam pengelolaan limbah industri dan hilirisasi industri berbasis sumberdaya alam lokal, maka dilakukan upaya untuk mencari alternatif teknologi pemanfaatan limbah marmer dan batukapur seoptimal mungkin untuk pembuatan bata ekspose berbasis wolastonit sintetis. yang diharapkan dapat memberi nilai tambah.

Percobaan pemanfaatan limbah debu marmer dan abu terbang batubara untuk pembuatan ubin keramik pernah dilakukan pada tahun 2009 (Suripto, dkk., 2009). Komposisi bahan optimum yang ditemukan adalah 55\% abu terbang batubara, $25 \%$ debu marmer dan $20 \%$ lempung Plered, pada suhu pembakaran 1180 ${ }^{\circ} \mathrm{C}$. Ubin keramik yang dihasilkan memiliki karakteristik sebagai berikut : penyerapan air $22,18 \%$, porositas $37,16 \%$, permeabilitas 2,83 cc/jam.cm², kekerasan 4,5 skala Moh's, dan kuat lentur 74,21 kg/cm². Sarkar et al., 2006 dalam penelitiannya membuat ubin keramik menggunakan debu marmer dari jenis batukapur tersilifikasi dan abu terbang yang rendah kadar kapurnya, namun tinggi kadar aluminanya; dengan komposisi $75 \%$ debu marmer dan $25 \%$ abu terbang diperoleh ubin keramik pada suhu pembakaran $1200{ }^{\circ} \mathrm{C}$ ditahan selama 2 jam dengan porositas semu $45 \%$ volume dan kekuatan tekan $15 \mathrm{MPa}$. Fasa mineral yang terbentuk adalah anorthite, kuarsa dan fasa gelas.

Dalam penelitian ini akan dicoba pembuatan bata ekspose berbasis wolastonit sintetis dengan memanfaatkan limbah debu marmer atau batukapur (batugamping) yang dicampur dengan silika halus. Proses sintering bodi keramik dimaksudkan untuk mendapatkan tingkat porositas; bila porositasnya < 5\% termasuk bodi padat dan jika porositasnya 20 $30 \%$ termasuk bodi porus (Jianfeng et al, 2012). Dengan perkataan lain bodi keramik mempunyai tingkat porositas berkisar $5-30 \%$. Sedangkan apabila ditinjau dari permeabilitas bodi terhadap penetrasi air, bodi keramik akan termasuk permeable atau dapat dirembesi air bila nilai penyerapan air diatas $20 \%$ (SNI 0028-1987-A). Wolastonit $\left(\mathrm{CaSiO}_{3}\right)$ adalah salah satu mineral yang terbentuk dari campuran kalsium dan silika berwarna putihkrem, secara teoritis memiliki komposisi $\mathrm{CaO}$ $=48,3 \%$ dan $\mathrm{SiO}_{2}=51,7 \%$. Sifat-sifat baik yang dimiliki antara lain sifat heat loss dan koefisien muai panjang yang rendah, susut bakar dan densitas yang relatif kecil, porositas yang besar namun masih memiliki kekuatan yang cukup baik pada kondisi sinter yang normal, serta memiliki sifat tahan api suhu rendah sehingga dapat digunakan sebagai bahan tahan api isolasi (Adylov et al. 2012). Wolastonit dapat diperoleh dari alam atau buatan maupun sintetis. Wolastonit alam umumnya berupa $\beta$-wolastonit yang sulit diperoleh dalam jumlah besar. Sedangkan wolastonit sintetis tergan-tung dari suhu pembakarannya yang dapat dibuat sebagai $\beta$ wolastonit atau sebagai $\alpha$-wolastonit (pseudowollastonite) sesuai kebu-tuhan. Pseudowollastonite terdapat dalam bentuk struktur kristal pseudo-hexagonal, sedangkan $\beta$ wolastonit terdapat dalam bentuk struktur kristal triklin (Kushiro, 2001; Yamanaka dan Mori, 2000). Wolastonit yang lazim dipasaran adalah wolastonit sintetis dalam bentuk $\beta$ wolastonit $\left(\beta-\mathrm{CaOSiO}_{2}\right)$ yang mempunyai harga koefisien muai panjang jauh lebih rendah dibandingkan $\alpha$-wolastonit. $\beta$-wolastonit akan 
berubah menjadi $\alpha$-wolastonit pada suhu 1125 ${ }^{\circ} \mathrm{C}$ dan $\alpha$-wolastonit sudah mengalami peleburan pada suhu $1140^{\circ} \mathrm{C}$ (Sulistarihani 1994; Adylov et al., 2012). Pembuatan $\beta$ wolastonit dipengaruhi oleh kualitas bahan baku, ukuran butir, kondisi pembakaran, jenis dan jumlah aditif atau dispersan yang ditambahkan (Sulistarihani, 1994). Jenis aditif anorganik yang sering dipakai di antaranya adalah poly ethylene glycol, dextrin, dan dolapic CE 64, calgon, atau SHMP (Nour et al., 2007). Pencampuran antara kalsium (batu kapur atau marmer) dengan silika secara homogen sesuai rasio molar $\mathrm{CaO}: \mathrm{SiO}_{2}=1$ : 1, dan dibakar pada suhu antara 1000 - 1100 ${ }^{\circ} \mathrm{C}$, dapat menghasilkan $\beta$-wolastonit dengan struktur mikro pori yang kuat (Demidenko dan Konkina, 2003).

\section{METODE}

Teknologi pembuatan bata ekspose berbasis bodi wolastonit pada prinsipnya mengatur komposisi bahan utama kalsium yaitu marmer atau batukapur bersama silika, dengan parameter perbandingan bahan utama dan variasi penambahan aditif pada temperatur sintering $1100{ }^{\circ} \mathrm{C}$, ditahan selama 3 jam. Bahan limbah marmer dan batukapur yang digunakan berasal dari Citatah Jawa Barat, sedangkan pasir silika dari PT. Sibelco, Cikarang, Jawa Barat. Bahan aditif yang digunakan adalah poly ethylene glycol (PEG) dan dextrin (DEX) sebagai perekat serta calgon sebagai dispersan. Fungsi aditif adalah untuk mengatur pembentukan pori sehingga luas permukaan kontak menjadi lebih besar pada rentang suhu bakar $1000-1150{ }^{\circ} \mathrm{C}$. Ronggarongga diantara butiran diharapkan membentuk struktur pori sehingga densitasnya menjadi ringan dengan kekuatan yang baik. Komposisi bahan utama marmer/kapur dan silika didesain berdasarkan perbandingan molar $\mathrm{CaO}: \mathrm{SiO}_{2}=1: 1,20$.

Sebanyak 12 komposisi benda uji/bodi telah dipersiapkan dengan perbandingan bahan yang telah ditentukan (Tabel 1). Bahan-bahan tersebut dicampur merata dan dimasukkan ke dalam cetakan benda uji, kemudian ditekan dengan menggunakan hydraulic press pada tekanan pembentukan $350 \mathrm{~kg} / \mathrm{cm}^{2}$. Bendabenda uji kemudian dikeringkan menggunakan electric drying cabinet selama 3 hari. Hari pertama dikeringkan pada suhu $75^{\circ} \mathrm{C}$, hari kedua pada suhu $100^{\circ} \mathrm{C}$, dan hari ketiga pada suhu $105^{\circ} \mathrm{C}$. Setelah benda uji menjadi kering dilakukan pengukuran panjang dan lebarnya, untuk menghitumg susut kering. Selanjutnya benda uji dibakar dalam tungku pembakaran pada suhu $1100{ }^{\circ} \mathrm{C}$. Benda uji yang sudah dibakar selanjutnya dikarakterisasi fisis antara lain : susut bakar, penyerapan air, porositas, densitas, kuat tekan dan kekerasan. Uji kuat tekan dilakukan dengan alat universal testing machine. Selain itu dilakukan analisis kimia dan mineralogi terhadap benda uji. Analisis mineral dilakukan dengan alat X-RD untuk mengetahui intensitas fasa kristalin wolastonit yang terbentuk pada benda uji. Analisis rasional mineral dilakukan untuk mengetahui jumlah persen fasa mineral yang terbentuk secara kuantitatif. Pelaksanaan percobaanpembuatan bata ekspose berbasis wolastonit ini dapat dilihat pada diagram alir Gambar 1.

Tabel 1. Desain komposisi bodi

\begin{tabular}{|c|c|c|c|c|}
\hline No & $\begin{array}{c}\text { Kode } \\
\text { komp. } \\
\text { Bodi }\end{array}$ & $\begin{array}{c}\text { Serbuk } \\
\text { kapur/ } \\
\text { marmer }\end{array}$ & $\begin{array}{c}\text { Serbuk } \\
\text { silika }\end{array}$ & $\begin{array}{c}\text { Aditf } \\
\text { PEG/Dex }\end{array}$ \\
\hline 1 & MP I & 55 & 45 & 10 \\
\hline 2 & MP II & 61 & 39 & 10 \\
\hline 3 & MP III & 67 & 33 & 10 \\
\hline 4 & MD I & 55 & 45 & 10 \\
\hline 5 & MD II & 61 & 39 & 10 \\
\hline 6 & MD III & 67 & 33 & 10 \\
\hline 7 & KP I & 55 & 45 & 10 \\
\hline 8 & KP II & 61 & 39 & 10 \\
\hline 9 & KP III & 67 & 33 & 10 \\
\hline 10 & KD I & 55 & 45 & 10 \\
\hline 11 & KD II & 61 & 39 & 10 \\
\hline 12 & KD III & 67 & 33 & 10 \\
\hline $\begin{array}{l}\text { Keter } \\
\text { MP } \\
M D \\
\text { KP } \\
\text { KD }\end{array}$ & $\begin{array}{l}\text { Ingan : } \\
=\text { Marmer } \\
=\text { Marmer } \\
=\text { Kapur + } \\
=\text { Kapur + }\end{array}$ & $\begin{array}{l}\text { EG } \\
\text { EX } \\
\text { G } \\
X\end{array}$ & & \\
\hline
\end{tabular}




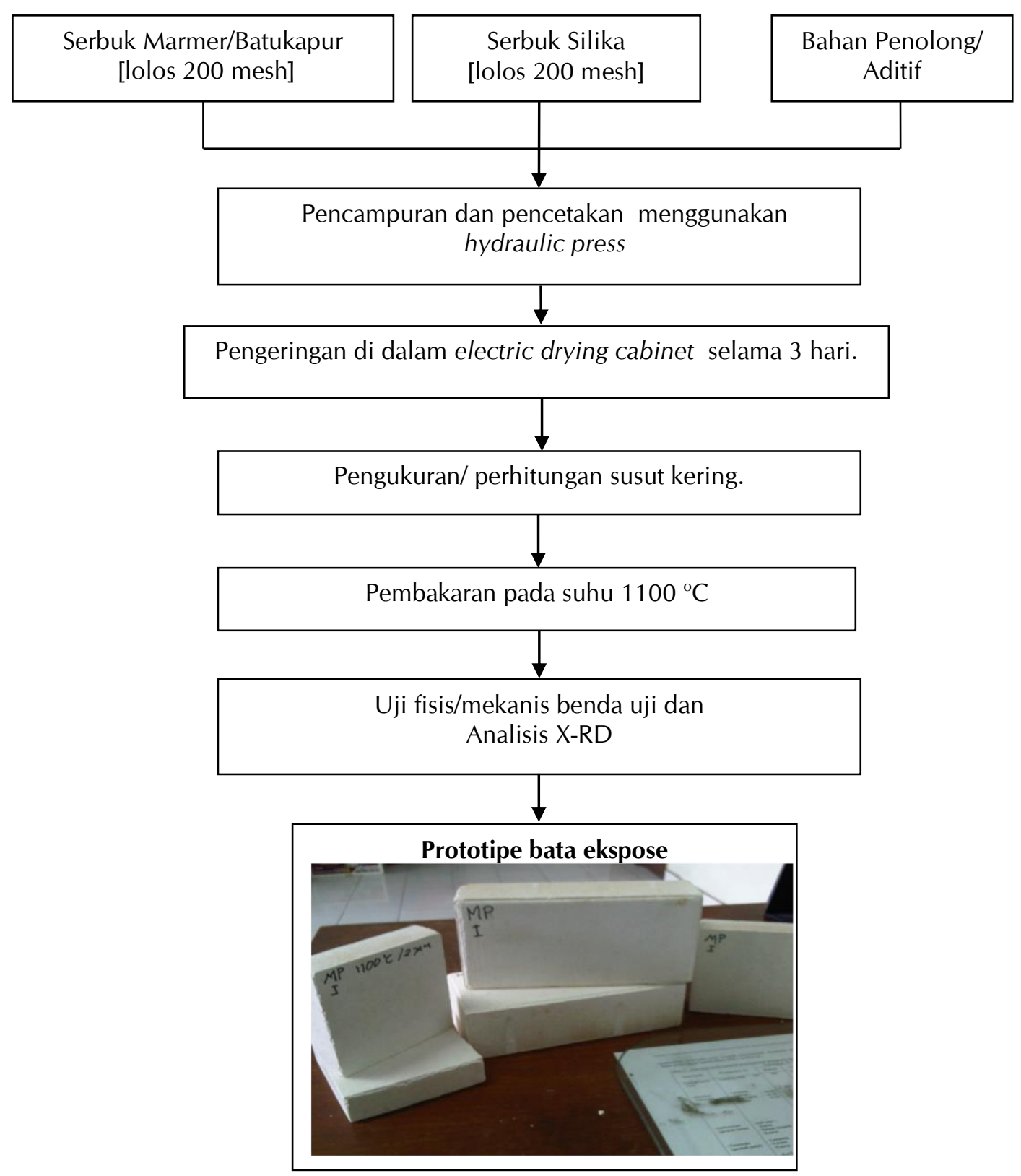

Gambar 1. Diagram alir percobaan pembuatan Bata Ekspose Wolastonit

\section{HASIL DAN PEMBAHASAN}

\section{Karakteristik Fisis dan Mekanis}

Hasil uji fisis dan mekanis benda uji setelah dibakar pada suhu $1100{ }^{\circ} \mathrm{C}$ dapat dilihat pada Tabel 2. Variasi komposisi dan aditif ternyata tidak berpengaruh banyak terhadap perubahan susut kering dan susut bakar benda uji. Susut kering dan susut bakar rata-rata nilainya relatif kecil yaitu masing-masing sebesar $4,21 \%$ dan $2,14 \%$. Sedangkan penyerapan air berbanding lurus dengan porositas, dengan kata lain semakin besar porositas benda uji maka semakin besar penyerapan airnya. Semakin banyak penambahan bahan utama kalsium (limbah marmer atau batukapur) pada komposisinya, cenderung menyebabkan semakin besar persentase porositas dan penyerapan airnya, hal ini disebabkan oleh jumlah bahan volatile $\left(\mathrm{CO}_{2}\right)$ yang dibebaskan lebih besar saat dibakar dan meninggalkan volume (pori) namun menyebabkan semakin kecil kekuatan mekanisnya (Jianfeng et al. 2012). Hasil pengujian terhadap benda uji MP I dan KP I 
dengan komposisi bahan 55\% Marmer atau Batu Kapur dan 45\% Silika, dengan penambahan aditif Poly Ethylene Glycol (PEG) memberikan kuat tekan sedikit lebih tinggi dibanding dengan komposisi bodi lainnya, yaitu sebesar 12,7 Mpa untuk benda uji MP I dan sebesar 13,1 Mpa untuk benda uji KP I. Uji kekerasan bodi berdasarkan skala Moh's menunjukkan benda uji KP I dan MP I dengan komposisi optimal 55\% kapur atau marmer dan $45 \%$ silika menghasilkan angka kekerasan 4 - 5 (skala Moh's) yang relatif lebih keras dibanding komposisi benda uji lainnya, hal ini disebabkan pada komposisi optimal tersebut telah terbentuk fasa mineral sekunder wolastonit pada suhu sintering $1100{ }^{\circ} \mathrm{C}$ sehingga berpengaruh terhadap peningkatan kekuatan mekanis benda uji. Pada suhu sintering tersebut benda uji sudah sangat padat hal ini terbukti dari nilai kekuatan tekan sebesar > $100 \mathrm{~kg} / \mathrm{cm}^{2}$. Secara stoikiometri reaksi antara $\mathrm{CaO}$ dan $\mathrm{SiO}_{2}$ pada suhu pembakaran $1125^{\circ} \mathrm{C}$ sudah terbentuk reaksi wolastonit $\left(\mathrm{CaSiO}_{3}\right)$ yang tervitrifikasi secara sempurna (Philippe et al. 2007). Penambahan aditif PEG (Poly Ethylene Glycol) pada komposisi tersebut juga memberi pengaruh yang cukup signifikan terhadap kekuatan mekanis benda uji hingga dua kali lebih besar dibanding penambahan aditif Dextrin, karena PEG memiliki tingkat polimerisasi dan luas permukaan (surface area) yang lebih baik serta mudah larut dalam air dibanding Dextrin.

Menurut Philppe et al. 2007 pemakaian PEG dalam campuran komposisi bodi keramik sebanyak 2-3\% sudah berfungsi sangat baik sebagai binder.

\section{Karakteristik Kimia dan Mineralogi}

Hasil analisis kimia dari bahan baku yang digunakan untuk pembuatan bata ekspose berbasis wolastonit sintetis ini dapat dilihat pada Tabel 3, dan untuk komposisi benda uji dapat dilihat pada Tabel 4. Dari komposisi bahan baku menunjukkan bahwa debu marmer atau batu kapur yang digunakan termasuk batukapur kalsit dengan kadar $\mathrm{CaO}$ cukup tinggi mendekati $56 \%$. Demikian pula kandungan $\mathrm{SiO}_{2}$ pada silika cerasil cukup murni diatas $95 \%$. Kadar senyawa oksida besi $\left(\mathrm{Fe}_{2} \mathrm{O}_{3}\right)$ dalam silika yang sangat kecil sebesar $0,07 \%$, tidak berpengaruh terhadap terbentuknya wolastonit $\left(\mathrm{CaOSiO}_{2}\right)$, meskipun terbentuknya senyawa $\mathrm{CaO} \quad \mathrm{Fe}_{2} \mathrm{O}_{3}$ sangat mungkin terjadi mulai suhu pembakaran 900 ${ }^{\circ} \mathrm{C}$ tetapi jumlahnya relatif sangat kecil, terbukti dari hasil pembakaran benda uji yang berwarna putih bersih.

Tabel 3. Komposisi Kimia Bahan Baku Utama

\begin{tabular}{lllll} 
& & & & Satuan: $\%$ \\
\hline No. & $\begin{array}{l}\text { Unsur } \\
\text { Kimia }\end{array}$ & $\begin{array}{l}\text { Debu } \\
\text { marmer } \\
\text { Padalarang }\end{array}$ & $\begin{array}{l}\text { Kapur } \\
\text { Padala- } \\
\text { rang }\end{array}$ & $\begin{array}{l}\text { Silika } \\
\text { Cerasil }\end{array}$ \\
\hline 1 & $\mathrm{SiO}_{2}$ & 1,04 & 1,58 & 96,97 \\
2 & $\mathrm{Al}_{2} \mathrm{O}_{3}$ & $<\mathrm{LOD}$ & $<\mathrm{LOD}$ & 0,68 \\
3 & $\mathrm{Fe}_{2} \mathrm{O}_{3}$ & 0,04 & 0,06 & 0,07 \\
4 & $\mathrm{TiO}_{2}$ & $<$ LOD & $<$ LOD & 0,11 \\
5 & $\mathrm{CaO}$ & 55,34 & 53,52 & 0,56 \\
6 & $\mathrm{MgO}$ & 0,25 & 0,98 & 0,54 \\
7 & $\mathrm{Na} 2 \mathrm{O}$ & 0,25 & 0,22 & 0,17 \\
8 & $\mathrm{~K} 2 \mathrm{O}$ & 0,05 & 0,20 & 0,64 \\
9 & $\mathrm{Hilang}$ & 43,03 & 43,20 & 0,26 \\
\hline
\end{tabular}

Ket : Limit Of Detection (LOD): $\mathrm{Al}_{2} \mathrm{O}_{3} 0,17 \%, \mathrm{TiO}_{2}$ 0,07 $\%$

Tabel 2. Hasil uji fisis dan mekanis benda uji pada suhu pembakaran $1100{ }^{\circ} \mathrm{C}$

\begin{tabular}{|c|c|c|c|c|c|c|c|c|c|}
\hline \multirow{2}{*}{ Kode } & \multicolumn{2}{|c|}{ Susut Kering (\%) } & \multicolumn{2}{|c|}{ Susut Bakar (\%) } & \multirow{2}{*}{$\begin{array}{c}\text { Penyerapan } \\
\text { Air (\%) }\end{array}$} & \multirow{2}{*}{$\begin{array}{c}\text { Porositas } \\
(\%)\end{array}$} & \multirow{2}{*}{$\begin{array}{c}\text { Densitas } \\
\text { (g/cc) }\end{array}$} & \multirow{2}{*}{$\begin{array}{c}\text { Kuat Tekan } \\
\text { (MPa) }\end{array}$} & \multirow{2}{*}{$\begin{array}{c}\text { Kekerasan } \\
\text { (Moh's) }\end{array}$} \\
\hline & SK pjg & SK Ibr & SB pjg & SB lbr & & & & & \\
\hline$\overline{M P I}$ & 4 & 5 & $-1,92$ & $-2,44$ & 35,72 & 52,55 & 1,47 & 12,708 & 4 \\
\hline MP II & 4,4 & 4,6 & $-2,64$ & $-2,31$ & 38,45 & 55,49 & 1,44 & 8,796 & $3-4$ \\
\hline MP III & 4 & 4,8 & $-2,25$ & $-2,19$ & 39,3 & 56,24 & 1,43 & 6,907 & $2-3$ \\
\hline MD I & 4,2 & 4,8 & $-2,08$ & $-1,47$ & 40 & 56,72 & 1,42 & 6,62 & $2-3$ \\
\hline MD II & 4,2 & 4,6 & $-2,01$ & $-1,43$ & 41,35 & 58,26 & 1,41 & 5,337 & $2-3$ \\
\hline MD III & 4 & 5 & $-0,1$ & $-2,32$ & 43,69 & 60,8 & 1,39 & 5,787 & $2-3$ \\
\hline KP I & 4,4 & 4,6 & $-2,92$ & $-2,72$ & 31,79 & 47,8 & 1,51 & 13,094 & $4-5$ \\
\hline KP II & 4,2 & 4,8 & $-2,84$ & $-2,23$ & 34,03 & 51,39 & 1,52 & 8,153 & $3-4$ \\
\hline KP III & 3,96 & 4,8 & $-2,21$ & $-2,31$ & 41,6 & 58,59 & 1,41 & - & - \\
\hline KD I & 4,6 & 4,6 & $-2,48$ & $-2,85$ & 44,27 & 61,07 & 1,38 & 6,266 & $2-3$ \\
\hline KD II & 4,4 & 4,3 & $-2,09$ & $-2,18$ & 40,4 & 57,4 & 1,42 & - & - \\
\hline KD III & 4,16 & 4,6 & $-2,13$ & $-2,4$ & - & - & - & - & - \\
\hline
\end{tabular}


Tabel 4. Komposisi Kimia Benda Uji MP I dan KP I

\begin{tabular}{clcc} 
& & & Satuan: $\%$ \\
\hline No. & Unsur Kimia & KP I & MP I \\
\hline 1 & $\mathrm{SiO}_{2}$ & 56,0 & 55,67 \\
2 & $\mathrm{Al}_{2} \mathrm{O}_{3}$ & 0,68 & 0,25 \\
3 & $\mathrm{Fe}_{2} \mathrm{O}_{3}$ & 0,22 & 0,25 \\
4 & $\mathrm{TiO}_{2}$ & 0,05 & 0,03 \\
5 & $\mathrm{CaO}$ & 37,81 & 39,88 \\
6 & $\mathrm{MgO}$ & 0,40 & 0,13 \\
7 & $\mathrm{Na} 2 \mathrm{O}$ & 2,25 & 1,75 \\
8 & $\mathrm{~K} 2 \mathrm{O}$ & 0,43 & 0,60 \\
9 & Hilang Pijar & 2,16 & 1,18 \\
\hline
\end{tabular}

Gambar 2 menunjukkan difraktogram hasil analisis XRD benda uji MP I setelah pembakaran pada suhu $1100{ }^{\circ} \mathrm{C}$ dengan penahanan selama 3 jam, terlihat fasa $\beta$ wolastonit yang terbentuk masih sangat kecil dengan intensitas yang lemah, hal ini disebabkan marmer berasal dari hasil rekristalisasi batukapur pada kondisi tekanan dan termal yang cukup tinggi sehingga struktur kristal marmer menjadi lebih stabil dibanding batukapur, hal ini diperkirakan akan mempengaruhi transformasi pembentukan mineral sekunder wolastonit. Berbeda dengan difraktogram hasil XRD benda uji KP I (Gambar 3) setelah pembakaran pada suhu yang sama, fasa $\beta$-wolastonit yang terbentuk lebih dominan dengan intensitas yang cukup tinggi meskipun masih tercampur $\mathrm{SiO}_{2}$. Untuk mengetahui jumlah persen (\%) fasa mineral yang terbentuk secara kuantitatif, digunakan metode analisis perhitungan rasional dengan menggabungkan hasil analisis XRD (Gambar 2 dan 3) dengan hasil analisis kimia (Tabel 4) yaitu dengan cara mengasumsikan bahwa jenis mineral yang terbentuk mempunyai rumus tertentu yang jumlah persen oksidanya dapat menentukan jumlah mineralnya (Sena da Fonseca, et al. 2013). Hasil analisis rasional pada Tabel 5 menunjukkan secara kuantitatif jumlah persen mineral yang terbentuk pada benda uji KP I dan MP I setelah dibakar pada suhu sintering $1100^{\circ} \mathrm{C}$. Keberadaan wolastonit pada benda uji KP I lebih dominan hingga mencapai 80,02\% tanpa menyisakan residu kalsium silikat, diduga karena kandungan kalsium terhadap silikat dalam pembentukan fasa wolastonit lebih reaktif dibanding benda uji MP I dimana fasa wolastonit yang terbentuk hanya sebesar $41,84 \%$ sehingga masih menyisakan residu kalsium silikat sebesar $41,84 \%$.

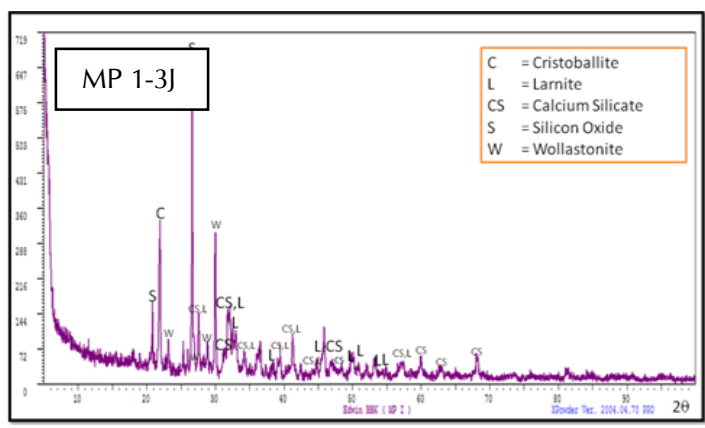

Gambar 2. Difraktogram hasil analisis X-RD untuk benda uji MP 1

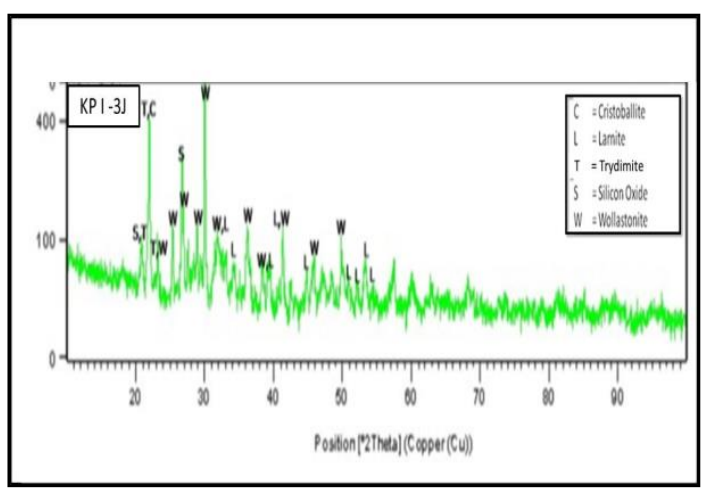

Gambar 3.Difraktogram hasil analisis XRD untuk benda uji KP 1

Tabel 5. Analisis Rasional Mineral

\begin{tabular}{clcc} 
& & & Satuan : \% \\
\hline No. & Komp. Mineral & MP I & KP I \\
\hline 1 & Wolastonit & 41,84 & 80,02 \\
2 & Larnite & 4,92 & 6,38 \\
3 & Kalsium Silikat & 41,84 & - \\
4 & Kristobalit, Trydimit, & 11,39 & 13,6 \\
\hline
\end{tabular}

\section{Nilai Ekonomi Bata Ekspose Wolastonit}

Sebagai gambaran didasarkan atas hasil percobaan pembuatan komposisi bodi atau bata ekspose wolastonit dengan cara pembentukan pres kering diperlukan pemakaian bahan baku (tepung kapur, silika dan bahan penolong) sebanyak $250 \mathrm{~kg}$ dengan biaya sebesar Rp.3.052.000,- . Selain itu diperlukan biaya utilitas dan upah langsung sebesar Rp.1.950.000,- sehingga total biaya langsung sebesar Rp.3.052.000,- + Rp.1.950.000,- = Rp. 5.002.000,- Untuk biaya tidak langsung seperti pemakaian bahan 
bakar gas, penyusutan \& pemeliharaan alat/mesin dan biaya administrasi yaitu sebesar Rp.2.550.000,-. Total biaya langsung dan tak langsung bata ekspose wolastonit adalah sebesar Rp.5.002.000,- + Rp. 2.550.000,- = Rp. 7.552.000,- Dari total biaya tersebut diatas diperoleh perkiraan harga pokok produksi bata ekspose wolastonit sebesar Rp.7.552.000,- : $250 \mathrm{~kg}=$ Rp.30.208 per 10 buah atau Rp.3000,- per buah ukuran bata $20 \times 10 \times 5 \mathrm{~cm}$. Sementara harga pasaran saat ini untuk bata sejenisnya seperti bata isolasi jenis samot mencapai lebih dari Rp. 10.000,- per buah. Oleh karena itu, pembuatan bata ekspose wolastonit yang bersifat permeable ini dapat dikembangkan.

\section{KESIMPULAN DAN SARAN}

Bata ekspose berbasis bodi wolastonit sintetis dapat dibuat dengan komposisi optimum campuran bahan 55\% serbuk marmer/ batukapur dan $45 \%$ silika dengan kadar air 8 $\%$, suhu bakar $1100{ }^{\circ} \mathrm{C}$ ditahan selama 3 jam. Peningkatan pertumbuhan fasa mineral wolastonit pada suhu pembakaran optimal $1100{ }^{\circ} \mathrm{C}$ memberi pengaruh signifikan terhadap peningkatan kekuatan mekanis bodi. Nilai penyerapan air diatas $20 \%$ menunjukkan bodi keramik bersifat permeable atau dapat dirembesi air sesuai persyaratan SNI 0028-1987-A.

Karena ketersediaan bahan baku yang berlimpah di Indonesia, selain digunakan untuk dinding bangunan dapat dikembangkan pula sesuai kebutuhan antara lain untuk pedestrian atau jalan taman yang dapat menyerap air dan untuk bata isolasi jenis samot dalam tungku pembakaran.

\section{UCAPAN TERIMA KASIH}

Ucapan terimakasih disampaikan kepada anggota tim peneliti dan perekayasa di Balai Besar Keramik atas kerjasamanya dan kepada redaksi Jurnal Tekmira yang telah banyak membantu hingga dimuatnya karya tulis ini.

\section{DAFTAR PUSTAKA}

Adylov G.T, Voronov G.V, Gamostaeva S.A, Kulagiva N.A, Mansurova E.P, Rumi M.Kh.
2012. Use of wollastonite from the Koitashskae Deposit in the Production of lining bricks, Journal of Refractories and Industrial Ceramics, 43[11], pp.359-361.

SNI 0028-1987-A, Badan Standar Nasional Indonesia.

Demidenko, N.I. and Konkina, E.S. 2003. Sintering of Ceramic Mixtures Based on Natural Wollastonite, Glass and Ceramics 6 [1/2], pp.17-18.

Philippe Boch and Jean Claude Niepce, 2007. Ceramics Materials, Process, Properties and Applications, Penerbit ISTE. Ltd., USA, pp.184-187.

Jianfeng W.U, Guanghui LENG, Xiaohong XU, Yaxiang ZHANG, Xinbin LAO, Li Kun. 2012. Preparation and Properties of Ceramic Facing Brick from East Lake Sediment, Journal of Wuhan University of Technology Material Science, Volume 27, Issue 1, pp.154-159.

Kushiro, L., 2001. Wollastonit -pseudowollastonite inversion, Year Book - Carnegie Inst. Washington 63, pp. $83-84$.

Nour, W.M.N, Mostofa A.A, Ibrahim, D.M. 2007. Ceramics on Synthetic Wollastonite, Interceram, Vol.56 [6], pp. 424 - 428.

Sulistarihani, N., 1994. Pembuatan Wolastonit dengan cara pembakaran, Prosiding Seminar Hasil Litbang Industri Keramik, Balai Besar Keramik, hal. 21-29.

Sarkar R, Das S.K, Mandal P.K, Maiti H.S. 2006. Phase and Microstructure Evolution During Hydrothermal Solidification of Clay-Quartz Mixture with Marble Dust Source of Reactive Lime, Journal of European Ceramics Society, 26, pp.297-304.

Suripto, Pujiono dan Muchtar, 2009. Pemanfaatan Limbah Abu Terbang Batu Bara dan Limbah Debu Marmer Untuk Bahan Baku Pembuatan Ubin Keramik, Jurnal Keramik \& Gelas Indonesia, Vol. 18 No. 1, hal. $50-60$.

Sena da Fonseca B, Simao JAR, Galhano C. 2013. Effect of Coastal Environment in Clay Facing Bricks and Roof Tiles, Annual International Interdisciplinary Conference, AlIC, 24-26 April, Azores-Portugal, pp. 145.

Tushadi, 1990. Bahan Galian Industri Indonesia, Direktorat Sumberdaya Mineral, Direktorat Jenderal Geologi dan Sumberdaya Mineral, Departemen Pertambangan dan Energi, hal 423. 
Yamanaka, I., Mori, H., 2000. The structure and polytypes of Alpha $\mathrm{CaSiO}_{3}$

(Pseudowollastonite). Acta. Crystallogr. Sect.B, Struct. Crystallgr. Chem. B37, pp.1010 $-1017$. 